\title{
THE EFFECTS OF LARGE INTRAVENOUS INFUSIONS ON BODY FLUID ${ }^{1}$
}

\author{
By JOHN D. STEWART AND G. MARGARET ROURKE \\ (From the Surgical Laboratories of the Harvard Medical School at the \\ Massachusetts General Hospital, Boston)
}

(Received for publication October 28, 1941)

Much consideration has been given to the changes which result in man and in experimental animals from administering by vein various quantities of fluids of different composition $(1,2,3)$. Thus, the dislocation of body fluid and the urinary changes which follow rapid infusion of massive quantities of fluid in animals have been described $(4,5,6)$. Shifts of water and salts between muscle and blood after infusion of isotonic fluids of varying $\mathrm{pH}$ have been studied in dogs by means of muscle biopsy and analysis (7). The circulatory effects of administering fluid by vein in various clinical conditions have been investigated, having in mind the primary importance of circulatory dynamics in determining response to intravenous fluid therapy $(1,8)$. Such studies have served to emphasize the fundamental conclusions of Gamble $(9,10,11)$, Peters $(12,13)$, and others.

In the work on which the present report is based it seemed desirable to determine the results of large amounts of isotonic glucose and $\mathrm{NaCl}$ solutions administered by constant intravenous drip over a period of several days. The physiological responses to sustained submaximal infusions were under inquiry rather than the reaction to a large or small intravenous injection of brief duration, for it seemed possible that compensatory mechanisms of a different nature might be brought into play as the infusions were continued.

\section{MATERIAL AND METHODS}

Patients undergoing mild or moderately severe operations under ether anesthesia were studied just before operation, just after operation, at the end of the infusion period, and several days afterwards when the effects of the infusion had subsided. Determinations were made on a fasting basis, and the patients took water as desired during the infusion period but were allowed only small amounts of fruit juices in addition. The patients

1 Aided by grants from the William F. Milton Fund, Harvard University, and the Josiah Macy, Jr. Foundation. were well-nourished women without cardiovascular or renal disease. During the study they were under constant observation by trained attendants and, if a patient objected, the infusion was discontinued. Urine was collected quantitatively by an indwelling catheter. Arm or leg veins were used for the infusion, the extremity being splinted, and except for slight redness about the needle in two or three instances no local reaction was noted. The patients were entirely afebrile, or nearly so, during the study. Intake of fluid by oral and intravenous routes and output of urine were totaled at 12-hour intervals. Four patients received 5 per cent glucose solution and six 0.9 per cent $\mathrm{NaCl}$ solution.

\section{ANALYTICAL METHODS}

Blood loss at operation was determined by the method of Gatch and Little (14), sodium of serum or plasma and of urine by the gravimetric technique of Butler and Tuthill (15), potassium by the method of Fiske and Litarczek (16), chloride by Wilson and Ball's method (17), carbon dioxide content of serum according to Van Slyke and Sendroy (18), total nitrogen by macro-Kjeldahl (19) on oxalated plasma or serum and urine, and nonprotein nitrogen of serum or plasma by micro-digestion and nesslerization. Serum albumin was determined by Howe's method (20). From the total protein of the serum and the serum albumin, colloid osmotic pressure ("oncotic pressure") was calculated, using the nomographic formula of Wells, Youmans, and Mills (21). Oxygen capacity was determined on heparinized venous blood drawn without stasis and equilibrated with room air at room temperature (22). Hematocrit readings were made by adding $4 \mathrm{cc}$. of blood to $1 \mathrm{cc}$. of 1.1 per cent sodium oxalate and centrifuging in hematocrit tubes until no further change in the reading occurred, precautions being taken against loss of carbon dioxide. In some of the patients receiving 5 per cent glucose by vein the urinary excretion of glucose was measured, but these data are not included as the losses were trivial.

Plasma volume was determined by the method of Gregersen and his coworkers (23), using the blue dye $\mathrm{T}-1824$, the serum concentrations being measured spectrophotometrically. "Available fluid" volume, taken as extracellular fluid volume plus the water of red blood cells, was determined as described by Stewart and Rourke (24). The patients were weighed on a stretcher fitting over silk scales which were accurate to within 10 grams. 


\section{RESULTS}

Data are presented as obtained in three of the more conclusive experiments. Patient R. H. who underwent colporrhaphy and uterine suspension under ether anesthesia received 26.69 liters of 0.9 per cent $\mathrm{NaCl}$ solution intravenously during a period of 96 hours, beginning immediately after operation. Convalescence was uneventful, and the patient seemed to have less than usual postoperative discomfort. There was no detectable edema at any time. Patient G. S., following colporrhaphy under ether anesthesia, received intravenously during a period of 144 hours 28.37 liters of 5 per cent glucose solution without any untoward clinical effects and without edema. $\mathrm{Pa}$ tient S. K., following a trivial surgical procedure consisting of uterine dilatation and curettage under ether anesthesia, was given 6.86 liters of 5 per cent glucose solution by vein during a 36-hour period. Signs of water intoxication appeared, including nausea and vomiting, epigastric distress, disorientation and excitement, culminating shortly in coma. The infusion was immediately discontinued and complete recovery occurred in a few hours without the need of giving salt solution. Convalescence was subsequently uninterrupted. The patient was a young woman, 20 years old, in good general condition and without detectable renal, cardiovascular or hepatic disease.

In Figure 1 are shown fluid intake and urine volume measurements in the three experiments, together with body weight before and after the infusion. Measurements of intake and urine volume do not, of course, permit complete appraisal of the state of water balance, for water of oxidation on the one hand and extrarenal loss of water on the other are not considered. Since the latter factors are roughly stationary, however, the values do show the trend of water balance. Comparison of the G. S. and S. K. data bring out clearly the lag in water removal, which together with lack of sodium conservation (Figure 4) produced a rapid reduction of plasma sodium concentration in patient $S$. $K$.

In Figure 2 are shown balance data with respect to sodium, chloride ion and potassium, as found in patient $R . H$. The record of cumulative sodium balance brings out the slowness with which the mechanisms governing extracellular fluid volume operate against an inflow of isotonic $\mathrm{NaCl}$ solution. For 4 days they succeed only in progressively reducing the rate of increment, but by the eighth period they finally have the upper hand. The tolerance which the body shows for increase

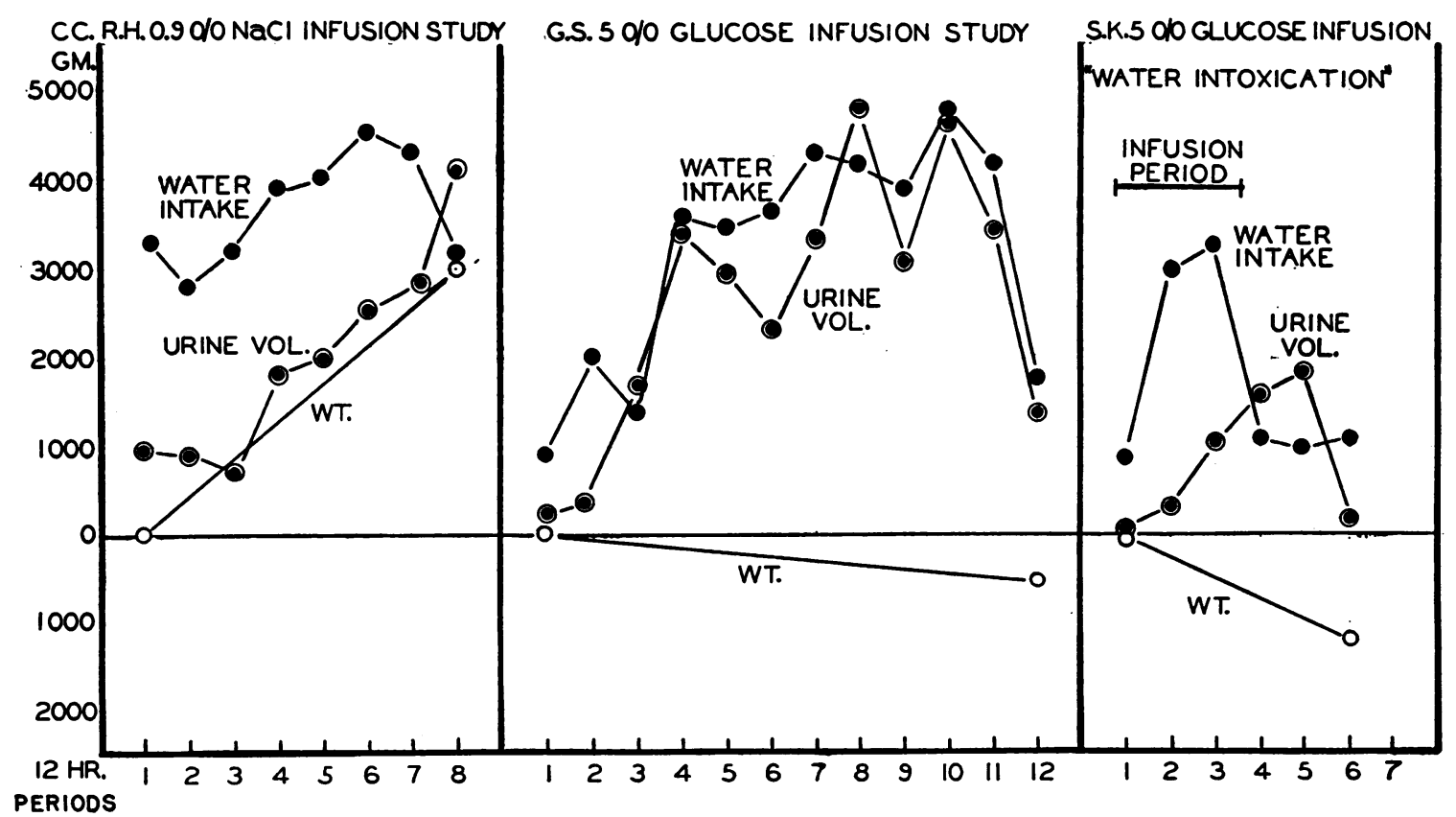

Fig. 1. Measurements of Body Weight Change, Total Water Intake and Urine Volume 


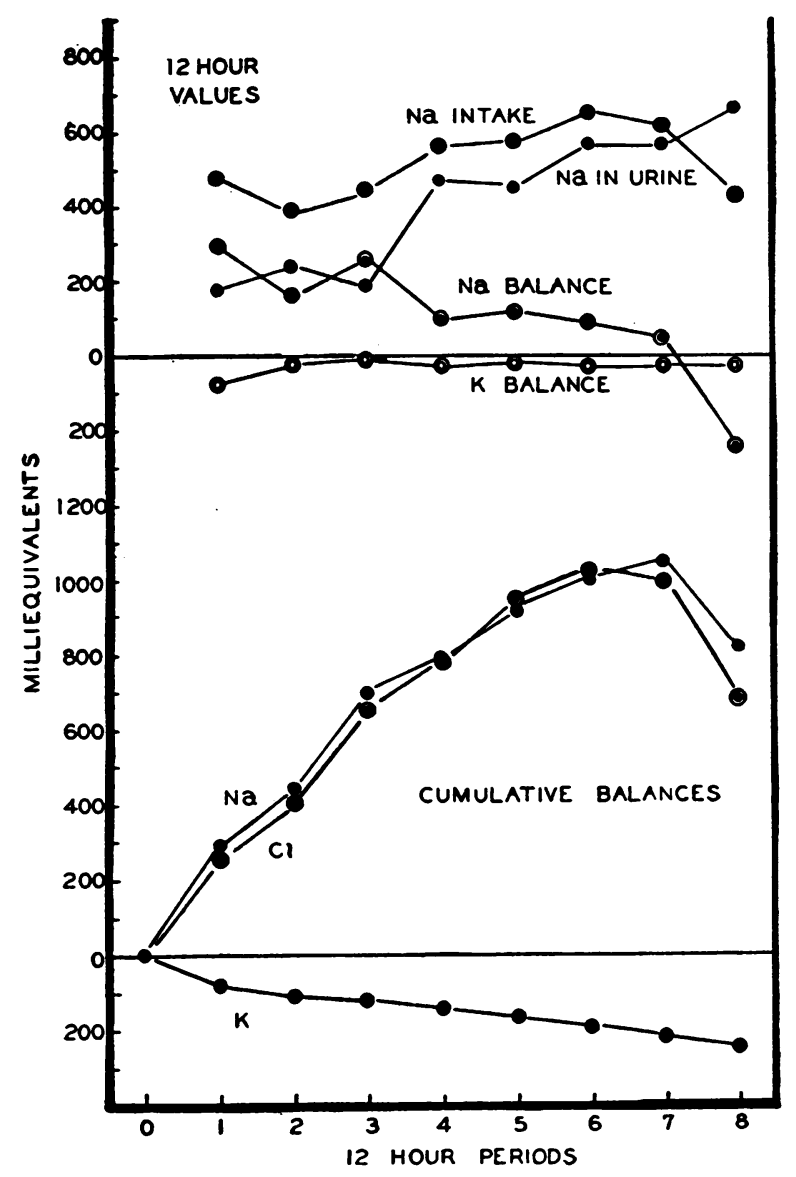

R.H. O.9 PER CENT N ACI INFUSION STUDY

Fig. 2. Electrolyte Balance Data from Salt INFUSION STUDY

in fluid when sodium and chloride ion are supplied with water is also indicated by the values shown in the upper half of the figure.

In Figure 3 are recorded the incidental losses of sodium, chloride ion, potassium and nitrogen. The scale of the nitrogen ordinate in grams is adjusted to that of the milliequivalent ordinate in terms of the nitrogen: potassium content of protoplasm (muscle).

The protein-sparing effect of glucose is shown by the more gradual loss of nitrogen for G. S. as compared with R. H. The loss of potassium in excess of nitrogen indicates withdrawal of intracellular fluid. The nitrogen-potassium discrepancy is much larger in the $\mathrm{NaCl}$ than in the glucose study. The total potassium loss for R. H. is 240 milliequivalents, while on the basis of nitrogen excretion 110 milliequivalents derive from destroyed protoplasm $(44 \times .2 .5=110)$. The remaining 130 milliequivalents correspond to 950 cc. of intracellular fluid. Such a relatively small loss from the body's total content of intracellular fluid is probably not physiologically significant. The discrepancy in the nitrogen-potassium elimination appears to be largely an initial event occurring in the early postoperative period. It is probably dependent to some extent on anesthesia and surgical trauma.

The loss of sodium over the 6 days of the glucose infusion in the case of patient G. S. was 289 milliequivalents. On the basis of the usual sodium content of interstitial fluid, 147 milliequivalents per liter, this implies a loss of $1960 \mathrm{cc}$. Total extracellular fluid for this patient estimated as 20 per cent of body weight is $13,660 \mathrm{cc}$. The loss would therefore amount to 14.5 per cent, a considerable but not a seriously large loss. In the case of S. K., however, a rapid loss of sodium from failure of renal conservation, together with the lag in water removal (Figure 1), produced a reduction of sodium concentration to a dangerous extent.

Figure 4 presents data on concentration of sodium in urine and plasma. The urine data from the $\mathrm{NaCl}$ study produce an impressive curve, which would seem to show quite clearly that the progressive decline in the rate of increase in extracellular fluid volume and the eventual reduction of volume are accompanied by an increasing removal of water with respect to sodium. The data from the glucose study (Patient G. S.) show very strikingly how extensive is the ability of the kidney to dilute sodium and how nearly the theoretically required zero excretion is approached. An approximately thirty-fold dilution of sodium with respect to its plasma level is attained. The data obtained from Patient S. K., in contrast with those from G. S., make clear the failure of this individual to conserve sodium in the presence of a large water excretion. In possible explanation it may be noted that $6867 \mathrm{cc}$. were given as compared with $3005 \mathrm{cc}$. for Patient G. S. over the first 30 hours of the infusion period, although thereafter this patient received approximately 6 liters per 24 hours without untoward effects. As seen in Figure 4, the urine 


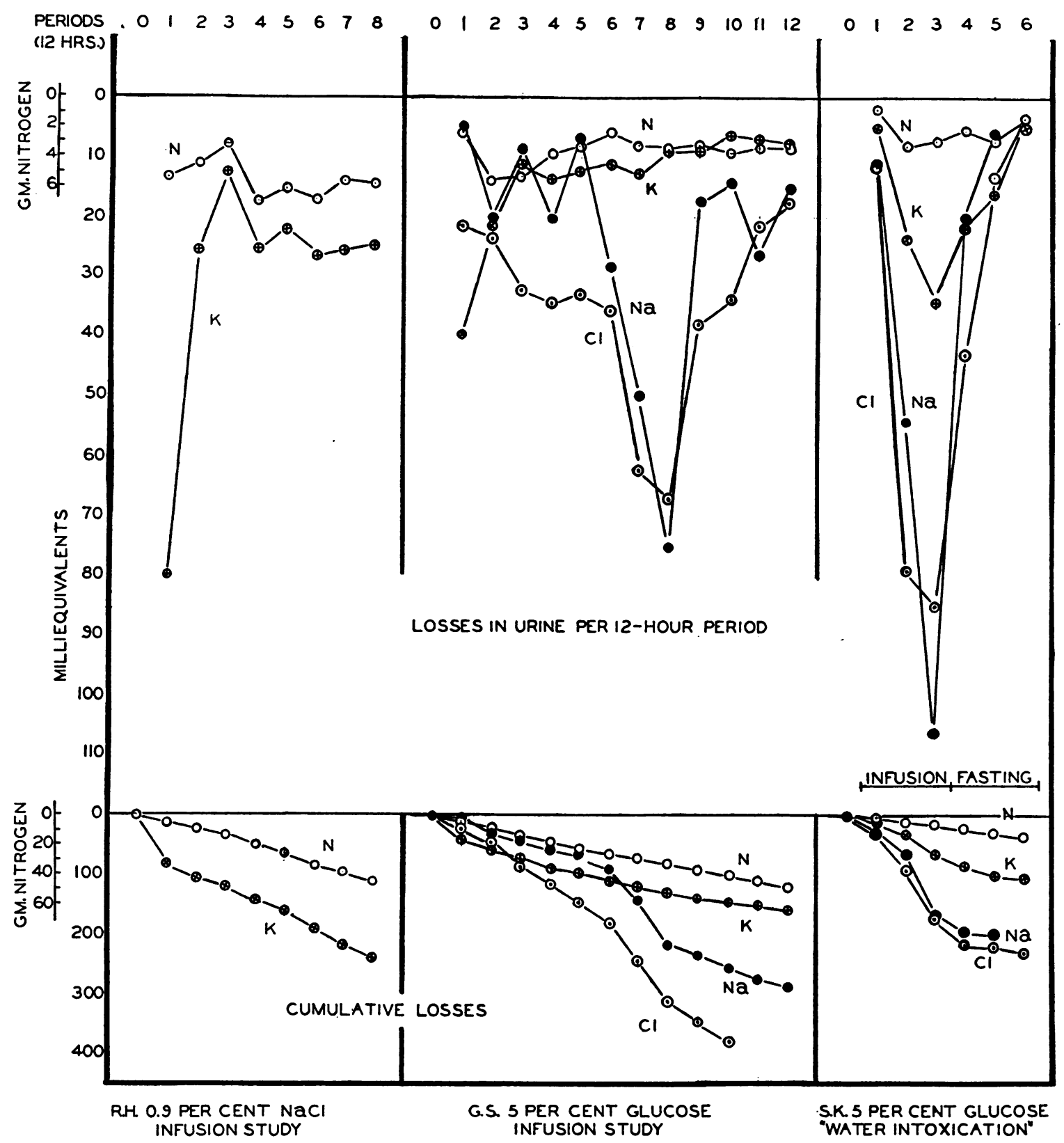

Fig. 3. Measurements of Losses of Nitrogen, Sodium, Chloride Ion and Potassium Incidental to Fasting

sodium concentrations for S. K. progressively decline during the period of water intoxication and with cessation of infusion fall at once to the extremely low level found for G. S. The data thus suggest that the load suddenly placed on renal regulation is larger than can be immediately managed.

Tables I, II and III show data obtained in study- ing the concentration of various factors in the blood during the progress of the experiments. "Available fluid" volume and plasma volume were also determined. The accuracy with which normal values are re-established after cessation of the infusion is strikingly shown in Table I. Table IV presents balance data for the infusion period in the three cases. 


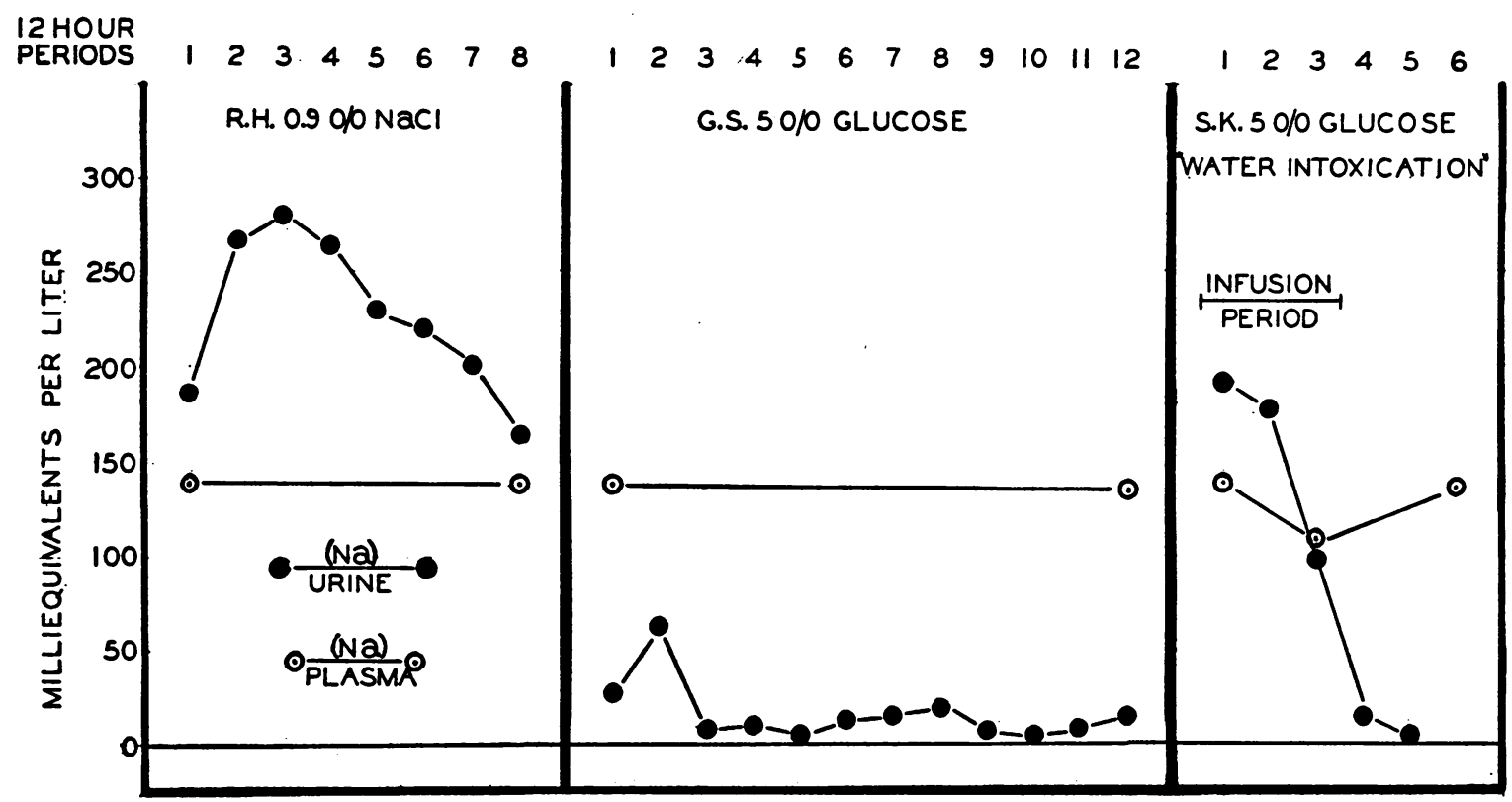

Fig. 4. Concentrations of Sodium in Urine and in Plasma

\section{DISCUSSION}

For the purposes of the experimental plan the patients studied were normal, healthy individuals, who were making uncomplicated recovery from moderate surgical trauma and ether anesthesia. As for the disturbances in body fluid connected with the anesthesia and operation in this group of cases, pertinent data have already been reported (25). At no time during the infusion did any of the patients show gross evidence of edema, a rather remarkable fact inasmuch as huge addi- tions to body fluid were made in the saline infusion studies. It is of interest also that the sensation of thirst was present, being perhaps more constant in the patients who were receiving glucose infusions.

These studies show sharp differences between the effects of isotonic sodium chloride solution and isotonic glucose solution when such solutions are given at a constant rate by vein over a period of several days. In general terms the saline solution tends to be retained, with consequent increase

TABLE I

\begin{tabular}{|c|c|c|c|c|}
\hline & Preoperative & Postoperative & $\begin{array}{l}\text { Infusion } \\
\text { stopped }\end{array}$ & Recovered \\
\hline 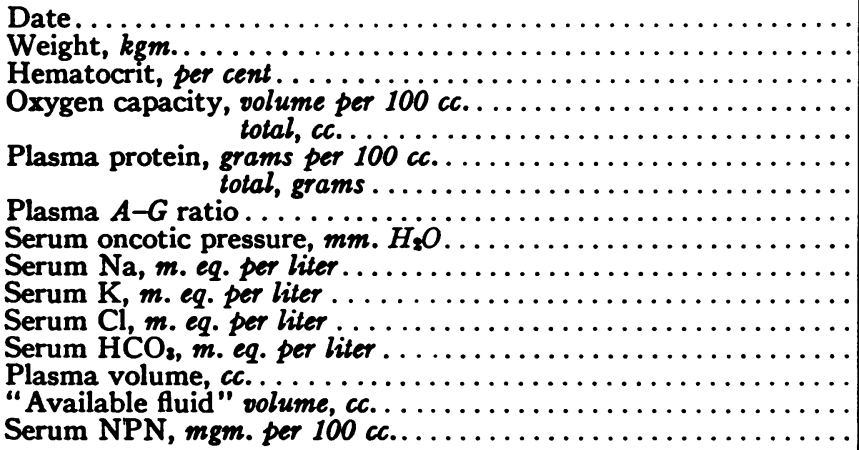 & $\begin{array}{c}\text { May } 19 \\
60.49 \\
42.8 \\
16.3 \\
841 \\
8.16 \\
246 \\
1.39 \\
410 \\
136.2 \\
3.9 \\
102.5 \\
26.8 \\
3013 \\
12130 \\
24.4\end{array}$ & $\begin{array}{c}\text { May } 19 \\
59.95 \\
41.9 \\
16.8 \\
869 \\
7.76 \\
233 \\
1.47 \\
392 \\
139.9 \\
3.9 \\
106.5 \\
24.7 \\
3008 \\
11960 \\
27.2\end{array}$ & $\begin{array}{c}\text { May } 24 \\
67.23 \\
25.6 \\
11.9 \\
757 \\
5.97 \\
283 \\
1.22 \\
247 \\
138.5 \\
3.8 \\
110.0 \\
22.4 \\
4730 \\
21850 \\
12.5\end{array}$ & $\begin{array}{c}\text { May } 28 \\
58.18 \\
33.3 \\
13.6 \\
633 \\
7.82 \\
243 \\
1.04 \\
350 \\
134.0 \\
4.6 \\
100.0 \\
29.2 \\
3106 \\
13970 \\
33.0\end{array}$ \\
\hline
\end{tabular}

R. H.-Infusion study, 0.9 per cent $\mathrm{NaCl}$ solution, 26.69 liters given. Operation consisting of colporrhaphy and uterine suspension, ether anesthesia. Blood loss $357 \mathrm{cc}$. 
TABLE II

\begin{tabular}{|c|c|c|c|}
\hline & $\begin{array}{l}\text { Preoper- } \\
\text { ative }\end{array}$ & $\begin{array}{l}\text { Postoper- } \\
\text { ative }\end{array}$ & $\begin{array}{l}\text { Infusion } \\
\text { stopped }\end{array}$ \\
\hline $\begin{array}{l}\text { Date. } \\
\text { Weight, } k g m . \\
\text { Serum protein, grams per } 100 \mathrm{cc} . \\
\text { Serum NPN, mgm. per } 100 \mathrm{cc} . \\
\text { Serum Na, m. eq. per liter } \\
\text { Serum Cl, m. eq. per liter }\end{array}$ & $\begin{array}{r}\text { June } 8 \\
69.83 \\
7.58 \\
21.2 \\
137.5 \\
106.0\end{array}$ & $\begin{array}{c}\text { June } 8 \\
68.35 \\
7.47 \\
19.2 \\
137.3 \\
106.0\end{array}$ & $\begin{array}{c}\text { June } 14 \\
67.88 \\
7.60 \\
15.0 \\
133.4 \\
91.0\end{array}$ \\
\hline
\end{tabular}

G. S.-Postoperative infusion study, 5 per cent glucose solution, 28.37 liters given. Operation consisting of colporrhaphy under ether anesthesia.

in plasma and extracellular fluid volume, dilution of plasma protein, and dilution of red blood cells. After a period of several days a maximal point is reached, the excretory mechanisms succeed in turning the tide, and urine volume equals or exceeds infusion volume. On the other hand, the infusion of isotonic glucose solution sets into
TABLE III

\begin{tabular}{|c|c|c|c|}
\hline & $\begin{array}{l}\text { Pre- } \\
\text { oper- } \\
\text { ative }\end{array}$ & $\begin{array}{l}\text { Post- } \\
\text { oper- } \\
\text { ative }\end{array}$ & $\begin{array}{c}\mathrm{Hy}- \\
\text { drated }\end{array}$ \\
\hline $\begin{array}{l}\text { Hematocrit, per cent } \\
\text { Oxygen capacity, volume per } 100 \mathrm{cc} \text {. } \\
\text { total, } c c \text {. } \\
\text { Plasma protein, grams per } 100 \mathrm{cc.} \text {, } \\
\text { tolal, grams } \\
\text { Plasma } \mathrm{A}-\mathrm{G} \text { ratio } \\
\text { Serum oncotic pressure, mm. } \mathrm{H}_{2} \mathrm{O} \\
\text { Serum Na, m. eq. per liter } \\
\text { Serum K, m. eq. per liter } \\
\text { Serum Ci, m. eq. per liter } \\
\text { Serum HCO, m. eq. per liter } \\
\text { Plasma volume, cc. } \\
\text { "Available fluid," volume, cc. } \\
\text { Serum NPN, mgm. per } 100 \mathrm{cc} \text {. }\end{array}$ & $\begin{array}{c}37.5 \\
16.3 \\
714 \\
7.66 \\
209 \\
1.54 \\
376 \\
140.5 \\
4.4 \\
105.0 \\
26.8 \\
2736 \\
11810 \\
23.4\end{array}$ & $\begin{array}{c}37.9 \\
16.0 \\
785 \\
7.67 \\
234 \\
1.59 \\
380 \\
138.3 \\
3.6 \\
105.0 \\
19.1 \\
3050 \\
11180 \\
23.1\end{array}$ & $\begin{array}{c}35.1 \\
15.0 \\
761 \\
7.20 \\
237 \\
1.25 \\
330 \\
112.0 \\
3.1 \\
86.5 \\
21.2 \\
3290 \\
15380 \\
13.2\end{array}$ \\
\hline
\end{tabular}

S. K.-Infusion study, 5 per cent glucose solution, duration 28 hours. Operation consisting of uterine curettage under ether anesthesia, blood loss $65 \mathrm{cc}$. Water intoxication and recovery.

immediate activity protective mechanisms through which the kidney defends the electrolyte com-

TABLE IV

Balance data

\begin{tabular}{|c|c|c|c|c|c|c|c|c|c|c|c|}
\hline \multirow[b]{2}{*}{ Study } & \multirow[b]{2}{*}{$\begin{array}{c}\text { 12-hour } \\
\text { period }\end{array}$} & \multicolumn{5}{|c|}{ Intake } & \multicolumn{5}{|c|}{ Urine } \\
\hline & & 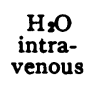 & $\begin{array}{c}\mathrm{H}_{2} \mathrm{O} \\
\text { post- } \\
\text { operative }\end{array}$ & $\begin{array}{l}\mathrm{H}_{2} \mathrm{O} \\
\text { total }\end{array}$ & $\mathrm{NaCl}$ & Glucose & Volume & $\mathrm{Na}$ & $\mathrm{Cl}$ & $\mathrm{K}$ & $\mathbf{N}$ \\
\hline \multirow[t]{2}{*}{$\begin{array}{l}\mathrm{I} \\
0.9 \text { per cent } \mathrm{NaCl} \text {, } \\
\text { Subject R. } \mathrm{H} \text {. }\end{array}$} & $\begin{array}{l}1 \\
2 \\
3 \\
4 \\
5 \\
6 \\
7 \\
8\end{array}$ & $\begin{array}{c}c c . \\
3,080 \\
2,545 \\
2,850 \\
3,615 \\
3,700 \\
4,224 \\
3,940 \\
2,740\end{array}$ & $\begin{array}{l}c c . \\
225 \\
270 \\
360 \\
330 \\
330 \\
360 \\
360 \\
360\end{array}$ & $\begin{array}{c}c c . \\
3,305 \\
2,815 \\
3,210 \\
3,945 \\
4,030 \\
4,584 \\
4,300 \\
3,100\end{array}$ & $\begin{array}{r}m E q . \\
476 \\
393 \\
441 \\
559 \\
572 \\
653 \\
609 \\
423\end{array}$ & grams & $\begin{array}{c}c c . \\
940 \\
880 \\
670 \\
1,760 \\
1,960 \\
2,540 \\
2,820 \\
4,065\end{array}$ & $\begin{array}{r}m E q . \\
178 \\
236 \\
186 \\
465 \\
453 \\
564 \\
563 \\
666\end{array}$ & $\begin{array}{r}m E q . \\
222 \\
246 \\
188 \\
422 \\
419 \\
574 \\
635 \\
739\end{array}$ & $\begin{array}{r}m E q . \\
79 \\
25 \\
12 \\
25 \\
22 \\
26 \\
26 \\
25\end{array}$ & $\begin{array}{r}\text { grams } \\
5.34 \\
4.47 \\
2.91 \\
6.92 \\
6.23 \\
6.73 \\
5.61 \\
5.70\end{array}$ \\
\hline & Total & 26,694 & 2,595 & 29,289 & 4,126 & & 15,635 & 3,311 & 3,445 & 240 & 43.91 \\
\hline \multirow[t]{2}{*}{$\begin{array}{l}\text { II } \\
5 \text { per cent Glucose, } \\
\text { Subject G. S. }\end{array}$} & $\begin{array}{r}1^{*} \\
2 \\
3 \\
4 \\
5 \\
6 \\
7 \\
8 \\
9 \\
10 \\
11 \\
12\end{array}$ & $\begin{array}{r}840 \\
1,135 \\
1,030 \\
2,530 \\
2,785 \\
2,565 \\
3,465 \\
3,213 \\
3,310 \\
3,702 \\
3,325 \\
475\end{array}$ & $\begin{array}{r}570 \\
285 \\
1,050 \\
705 \\
1,080 \\
885 \\
1,080 \\
540 \\
1,080 \\
900 \\
1,350\end{array}$ & $\begin{array}{r}840 \\
2,005 \\
1,315 \\
3,580 \\
3,490 \\
3,645 \\
4,350 \\
4,293 \\
3,850 \\
4,782 \\
4,225 \\
1,825\end{array}$ & & $\begin{array}{r}42 \\
57 \\
51 \\
126 \\
139 \\
128 \\
173 \\
160 \\
165 \\
185 \\
165 \\
23\end{array}$ & $\begin{array}{r}220 \\
325 \\
1,675 \\
3,480 \\
2,940 \\
2,325 \\
3,380 \\
4,735 \\
3,075 \\
4,690 \\
3,440 \\
1,365\end{array}$ & $\begin{array}{r}6 \\
21 \\
9 \\
20 \\
7 \\
28 \\
50 \\
75 \\
17 \\
14 \\
27 \\
15\end{array}$ & $\begin{array}{l}21 \\
23 \\
33 \\
35 \\
33 \\
36 \\
62 \\
67 \\
38 \\
34 \\
21 \\
18\end{array}$ & $\begin{array}{r}40 \\
21 \\
11 \\
13 \\
12 \\
11 \\
13 \\
8 \\
9 \\
6 \\
7 \\
8\end{array}$ & $\begin{array}{l}2.43 \\
5.77 \\
4.96 \\
3.83 \\
3.23 \\
2.44 \\
3.19 \\
3.41 \\
3.21 \\
3.79 \\
3.30 \\
3.43\end{array}$ \\
\hline & Total & 28,375 & 9,525 & 37,900 & & 1,414 & 31,650 & 289 & 421 & 159 & 42.99 \\
\hline \multirow[t]{4}{*}{$\begin{array}{l}\text { III } \\
5 \text { per cent Glucose, } \\
\text { Subject S. K. }\end{array}$} & $\begin{array}{l}1^{*} \\
2 \\
3\end{array}$ & $\begin{array}{r}750 \\
2,850 \\
3,267\end{array}$ & $\begin{array}{r}60 \\
165 \\
45\end{array}$ & $\begin{array}{r}810 \\
3,015 \\
3,312\end{array}$ & & $\begin{array}{r}37 \\
142 \\
163\end{array}$ & $\begin{array}{r}70 \\
305 \\
1,040\end{array}$ & $\begin{array}{r}12 \\
54 \\
106\end{array}$ & $\begin{array}{l}11 \\
79 \\
85\end{array}$ & $\begin{array}{r}6 \\
24 \\
34\end{array}$ & $\begin{array}{l}0.78 \\
3.31 \\
3.08\end{array}$ \\
\hline & Total & 6,867 & 270 & 7,137 & & 342 & 1,415 & 172 & 175 & 64 & 7.17 \\
\hline & 4 & 0 & 60 & 60 & & & 1,545 & 21 & 43 & 22 & 2.33 \\
\hline & 5 & 0 & 0 & 0 & & & 1,820 & 7 & 24 & 15 & 3.00 \\
\hline
\end{tabular}

* Six-hour period. 
position of the extracellular fluids, and large amounts' of urine are excreted containing extraordinarily little sodium and chloride. Dilution of plasma colloids and formed elements in the blood is accordingly averted. Putting it differently, the renal regulator is extremely sensitive to changes in composition of extracellular fluid, but is quite tolerant of increases in extracellular fluid volume.

It is evident that the administration of isotonic glucose solution by vein in the fasting subject results in reduced consumption of body protoplasm through the protein-sparing action of glucose. Such weight-conserving effects of glucose infusion are offset by the reduction in extracellular fluid stores accompanying the loss of sodium and chloride ion in the urine. The remarkable power of the healthy kidney to dilute sodium and chloride ion minimizes but does not entirely prevent the dehydrating action of isotonic glucose infusions. As shown in the study of Patient S. K., a dangerous body fluid disturbance may occur during the infusion of large amounts of isotonic glucose solution. The two factors which brought on the syndrome of water intoxication in this patient were retention of water without electrolyte, and failure in renal conservation of sodium and chloride ion.

A finding of interest was the mobilization of plasma protein by the saline infusion, but not at all, or much less extensively, by the glucose infusion. It would appear that reserve protein in the amount of 25 per cent or so of that in the plasma may be placed in circulation under conditions which tend to dilute plasma colloid, and apparently the loan is accurately paid back after the period of stress. If reliance can be placed on the albumin-globulin partition by the method used, then the reserve protein appears to be predominantly globulin. Nevertheless, the plasma benefits by an important increment in colloid osmotic pressure as a result of such additions. Presumably, large increases in plasma and extracellular fluid volume, as brought about by saline infusions, would be accompanied by increases in lymph and, if so, the total amount of extravascular circulating protein might also be augmented. It is a notable fact that the addition of plasma protein to the circulation taking place during saline infusions was unaccompanied by an increase in total circulating hemoglobin.
In considering values for extracellular fluid volume in these studies, it should be borne in mind that the thiocyanate ion is taken up by the water of red blood cells and, further, that at diffusion equilibrium between thiocyanate in serum and in transudates, the concentration in transudates is about $100 / 110$ of that in the serum (26). Consequently, the "available fluid for solution of thiocyanate" is to be regarded as only a rough approximation of true extracellular fluid volume, and the determination is of chief interest in showing changes in the same individual under varying conditions.

\section{CONCLUSIONS}

According to the data presented from three patients who underwent simple surgical procedures involving only slight loss of extracellular fluid, the chief effects of continued infusion of 0.9 per cent sodium chloride solution and of 5 per cent glucose solution on a basis of fasting are as follows:

Salt solution. Continuous infusion to the extent of 6.5 liters daily produces a very large addition to the volume of extracellular fluid, amounting to approximately 80 per cent of the initial volume. The daily increments, however, become progressively smaller and at the end of 3 to 4 days a maximum expansion of volume is reached which is followed by a gradual process of subsidence. In terms of initial volumes, the increase of interstitial fluid is approximately 90 per cent and that of blood plasma 60 per cent. An addition to the quantity of protein in plasma occurs to an extent which provides a protein concentration at nearly 6 grams per $100 \mathrm{cc}$. The circulation of extracellular fluid between the vascular and interstitial compartments is thus sustained and edema does not develop. Comparing the loss of nitrogen and potassium incidental to fasting with the $\mathrm{N}: \mathrm{K}$ ratio in muscle tissue, a relatively small withdrawal of intracellular fluid, 950 cc., is indicated.

The findings describe the surprising extent to which the extracellular fluid compartments can be overfilled without apparent evidence of functional disturbance.

Glucose solution. In contrast with the effect of salt solution, continuous infusion of $\mathbf{5}$ per cent 
glucose solution causes actual reduction of the volume of extracellular fluid, as evidenced by loss of body weight and of sodium. This dehydrating effect is referable to a not quite complete conservation of sodium by the kidney. Renal effectiveness in controlling the formation of an enormous quantity of urine ( 5 liters daily) under circumstances which severely test the reabsorptive mechanisms is, however, very remarkable. The concentration of sodium in the urine is held below $0.01 \mathrm{M}$ and sodium concentration in the plasma is almost completely sustained. A small protein-sparing effect from the glucose is shown by a 30 per cent reduction in the rate of nitrogen loss found in the salt infusion study. According to the relative quantities of nitrogen and potassium excreted in the urine, there is no appreciable withdrawal of intracellular fluid. The initial rate of glucose infusion was 2.4 liters per 24 hours. This was increased on the second day to approximately 6 liters.

According to evidence from a single patient, infusion of glucose solution at an initial rate of 5.5 liters per 24 hours may cause derangement of renal control of the electrolyte structure of the plasma (water intoxication). This is shown by a failure to conserve sodium and a consequent rapid fall of sodium concentration in the plasma. With cessation of infusion there is immediate recovery of renal control. The concentration of sodium falls in the urine and rises to its usual level in the plasma. The data clearly suggest overtaxing of the capacity of renal regulation.

These findings illustrate the fallacy of regarding glucose solution as a means of replacing losses of extracellular fluid and indicate the possible harmfulness of large infusions. They do not disturb the rationale of moderate amounts of glucose solution given intravenously to support renal function by providing a physiologically suitable volume of urine and to replace insensible expenditures of water.

Data in agreement with those presented were obtained from two patients given glucose solution and from five receiving salt solution.

The authors wish to thank Dr. James L. Gamble for help in the preparation of this paper.

\section{BIBLIOGRAPHY}

1. Murphy, F. D., Correll, H., and Grill, J. C., The effects of intravenous solutions on patients, with and without cardiovascular defects. J. A. M. A., 1941, 116, 104.

2. Blalock, A., Beard, J. W., and Thuss, C., Intravenous injections. A study of the effects on the composition of the blood of the injection of various fluids into dogs with normal and with low blood pressure. J. Clin. Invest., 1932, 11, 267.

3. Coller, F. A., Dick, V. S., and Maddock, W. G., Maintenance of normal water exchange with intravenous fluids. J. A. M. A., 1936, 107, 1522.

4. Cutting, R. A., Lands, A. M., and Larson, P. S., Distribution and excretion of water and chlorides after massive saline infusions. Arch. Surg., 1938, 36, 586.

5. Warthen, H. J., Massive intravenous injections. Arch. Surg., 1935, 30, 199.

6. Cutting, R. A., Larson, P. S., and Lands, A. M., Cause of death resulting from massive infusions of isotonic solutions. Arch. Surg., 1939, 38, 599.

7. Hastings, A. B., and Eichelberger, L., The exchange of salt and water between muscle and blood. I. The effect of an increase in total body water produced by the intravenous injection of isotonic salt solutions. J. Biol. Chem., 1937, 117, 73.

8. Gilligan, D. R., Altschule, M. D., and Volk, M. C., The effects on the cardiovascular system of fluids administered intravenously in man. I. Studies of the amount and duration of changes in blood volume. J. Clin. Invest., 1938, 17, 7.

9. Gamble, J. L., Ross, G. S., and Tisdall, F. F., The metabolism of fixed base during fasting. J. biol. Chem., 1923, 57, 633.

10. Gamble, J. L., and McIver, M. A., Body fluid changes due to continued loss of the external secretion of the pancreas. J. exper. Med., 1928, 48, 859.

11. Gamble, J. L., Extracellular fluid and its vicissitudes. Bull. Johns Hopkins Hosp., 1937, 61, 151.

12. Peters, J. P., Body Water: The Exchange of Fluids in Man. Charles C. Thomas, Baltimore, 1935.

13. Peters, J. P., The distribution and movement of water and solutes in the human body. Yale J. Biol. Med., 1933, 5, 431.

14. Gatch, W. D., and Little, W. D., Amounts of blood lost during some of the more common operations. J. A. M. A., 1924, 83, 1075.

15. Butler, A. H., and Tuthill, E., An application of the uranyl zinc method for determination of sodium in biological material. J. biol. Chem., 1931, 93, 171.

16. Folin, O., Laboratory Manual of Biological Chemistry. D. Appleton-Century Co., New York, 1934, Fifth ed.

17. Wilson, D. W., and Ball, E. G., A study of the estimation of chloride in blood and serum. J. biol. Chem., 1928, 79, 221. 
18. Van Slyke, D. D., and Sendroy, J., Jr., Carbon dioxide factors for manometric blood gas apparatus. J. biol. Chem., 1927, 73, 127.

19. Wong, S. Y., The use of persulfate in the estimation of nitrogen by the Arnold-Gunning modification of Kjeldahl's method. J. biol. Chem., 1923, 55, 427.

20. Howe, P. E., The use of sodium sulphate as the globulin precipitant in the determination of proteins in blood. J. biol. Chem., 1921, 49, 93.

21. Wells, H. S., Youmans, J. B., and Mills, D. G., A formula and monogram for the estimation of the osmotic pressure of colloids from the albumin and total protein concentrations of human blood sera. J. Clin. Invest., 1933, 12, 1103.

22. Van Slyke, D. D., and Neill, J. M., The determination of gases in blood and other solutions by vacuum extraction and manometric measurement. J. biol. Chem., 1924, 61, 523.

23. Gregersen, M. I., Gibson, J. J., and Stead, E. A., Plasma volume determination with dyes: errors in colorimetry; the use of the blue dye T-1824. Am. J. Physiol. (Proc.), 1935, 113, 54.

24. Stewart, J. D., and Rourke, G. M., On the measurement of extracellular fluid volume with thiacyanate, and body fluid analyses in 33 normal individuals. $\mathrm{J}$. Lab. and Clin. Med., 1941, 26, 1383.

25. Stewart, J. D., and Rourke, G. M., Changes in blood and interstitial fluid resulting from surgical operation and ether anesthesia. J. Clin. Invest., 1938, 17, 413.

26. Lavietes, P. H., Bourdillon, J., and Klinghoffer, K. A., The volume of the extracellular fluids of the body. J. Clin. Invest., 1936, 15, 261. 